\title{
Changes in the Hemoculture Methodology Improve the Test Positivity
}

\author{
Zélia M Profeta Luz
}

\author{
Laboratório de Malária, Centro de Pesquisas René Rachou-Fiocruz, Caixa Postal 1743, 30190-002 \\ Belo Horizonte, MG, Brasil
}

Key words: Chagas disease - hemoculture - diagnosis

In Chagas disease acute phase, diagnosis of infection can be based on parasitological methods, like for example the Strout or microhematocrit technique, which concentrate trypomastigotes of Trypanosoma cruzi, with sensitivities higher than 90\% (Flores et al. 1966, Fuente et al. 1985). Due to low levels of circulating parasites in the chronic phase of the disease, xenodiagnosis and hemoculture are more commonly used. These indirect methods are highly specific, but in general their sensitivities are rather low (Schenone et al. 1974, Coura et al. 1991, Chiari 1992). The Table summarizes some hemoculture and xenodiagnosis results as described in literature.

Several attempts have been made to improve the technique of hemoculture for the diagnosis of human Chagas disease (Neal \& Miles 1977). These authors observed that the choice of the medium and the protocols used were highly related to its results.

With the purpose to increase the sensitivity of the technique Chiari et al. (1989) utilized the following schedule: the packed red blood cells obtained from $30 \mathrm{ml}$ of heparinized blood were washed in phosphate buffer saline (PBS) or liver infusion tryptose (LIT) and then distributed into six tubes with $3 \mathrm{ml}$ of LIT medium and subsequently incubated at $28^{\circ} \mathrm{C}$. The authors observed a positivity of $55 \%(\mathrm{n}=40)$ by hemoculture in comparison to $27.5 \%$ by xenodiagnosis. The authors further concluded that the positivity was higher when LIT was used to wash the blood cells in comparison to PBS (Chiari et al. 1989).

The period of cultivation showed to be another relevant factor to increase the sensitivity of the hemoculture. Minter-Goedbloed et al. (1978) showed that the number of positive hemocultures

Fax:+55-31-295-3115.

E-mail: profeta@netra.cpqrr.fiocruz.br

Received 9 June 1999

Accepted 9 August 1999 increased when cultures were examined up to six months after inoculation. Using the method described by Chiari et al. (1989), Galvão et al. (1993) observed a positivity rate of $42 \%$ among 101 untreated subjects with Chagas disease. Some of these patients became only positive after 120 days of cultivation. We observed a positivity of $48 \%$ and $33 \%$, respectively, in hemocultures of 52 untreated chronic chagasic patients on day 30 and 60 post inoculation (PI). Neverthelss, $18 \%$ were only positive between 90 and 120 days PI (Luz et al. 1994). Recently, Junqueira et al. (1996) and Fernandes et al. (1995) also observed increased numbers of positive hemocultures (26.9\% and 56\% respectively) kept for 90 and 120 days.

Several authors showed that repeated hemocultures might increase the sensitivity for diagnosis of chronic patients. Albuquerque et al. (1972) observed a high positivity performing serial hemocultures of 38 chagasic patients (chronic phase) using Warren's medium. During three consecutive days three blood samples were collected, and repeated at monthly intervals. The accumulated positivity rate considering the first and second series gave a 37/38 (97.4\%) of positive patients. Mourão and Chiari (1975), using LIT and the protocol of Albuquerque et al. (1972) observed a positivity of $86.6 \%(n=13)$. In Argentina Jorg and Baez (1993), obtained a positivity rate of $86.6 \%$ in asymptomatic patients with chronic Chagas disease by repeating hemocultures until eight times using LIT.

To improve the sensitivity of the methodology described by Chiari (1989), we adapted the method by diminishing processment time of the blood samples (Luz et al. 1994) and observed a positivity of $94 \%$ among 33 chronic patients performing three tests. In a group of 52 subjects, we observed a high positivity (79\%) using only one test. In order to simplify the technique of hemoculture, to clarify the high positivity of the above mentioned study and to understand the controversial dates in the literature related to the sensitivity for the method, we evaluated factors possibly interfering with its positivity in artificial hemocultures (AH) 
TABLE

Positivity of hemoculture and xenodiagnosis in untreated patients with Chagas disease according to literature

\begin{tabular}{|c|c|c|c|c|}
\hline \multirow[t]{2}{*}{ Author (year) } & \multirow[t]{2}{*}{$\begin{array}{l}\text { Volume }(\mathrm{ml}) \text { of blood } \\
\text { used in hemoculture }\end{array}$} & \multirow[t]{2}{*}{$\begin{array}{l}\text { Patients } \\
\text { (n) }\end{array}$} & \multicolumn{2}{|c|}{$\begin{array}{c}\text { Parasitological tests } \\
(\% \text { positive })\end{array}$} \\
\hline & & & Hemoculture & Xenodiagnosis \\
\hline Freitas (1952) & 0.5 & 21 & 0 & 57 \\
\hline Pifano (1954) & 10 & 80 & 10 & 50 \\
\hline Chiari \& Brener (1966) & 15 & 35 & 25.7 & 31.4 \\
\hline Marsden et al. (1969) & 0.2 & 36 & 0 & 55 \\
\hline Albuquerque et al. $(1972)^{a}$ & 27 & 38 & 97.3 & ND \\
\hline \multirow{3}{*}{ Cerisola (1975) } & 3.0 & 14 & 7.1 & 35.7 \\
\hline & 15 & 43 & 2.3 & 53.5 \\
\hline & 0.2 & 68 & 2.9 & 42.7 \\
\hline Mourão \& Mello (1975) & 10 & 20 & 45 & ND \\
\hline Chiari \& Dias (1975) & 10 & 16 & 43.7 & ND \\
\hline Mourão \& Chiari (1975) ${ }^{a}$ & 27 & 15 & 86.6 & ND \\
\hline Minter-Goedbloed et al. (1978) & 0.2 & 16 & 44 & $e_{44,} f_{69}, g_{25}$ \\
\hline Chiari et al. (1989) & 30 & 40 & 55 & 30 \\
\hline Jorg \& Baez $(1993)^{a}$ & 15 & 90 & 86.6 & ND \\
\hline Galvão et al. (1993) & 30 & 101 & 47 & ND \\
\hline Barbosa et al. $(1983)^{d}$ & 10 & 250 & $0,20,60$ & 9 \\
\hline Fernandes et al. (1995) & 30 & 30 & 53.3 & 13.3 \\
\hline Mora (1996) & 30 & 85 & 40 & ND \\
\hline Junqueira et al. (1996) & 30 & 101 & 26 & 36 \\
\hline Luz (1998) & 30 & 162 & $90^{b}, 76^{c}$ & ND \\
\hline
\end{tabular}

$a$ : serial hemocultures; $b$ : serial hemocultures of $62 / 162$ patients; $c$ : only one hemoculture; $d$ : three different protocols; $e:$ T. infestans (5th instar), f: P. megistus (4th and 5th instar), g: P. megistus (1st instar); ND: not done.

(Luz 1998). AH were performed using human blood inoculated artificially with trypomastigotes isolated from mice infected with $T$. cruzi, strain Y, utilizing LIT or BHI (Brain Heart Infusion) as culture media. We studied the influence of size of the inoculum, the impact of centrifugation and temperature of samples before inoculation and the effect of time lapse between collection and inoculation of the sample in culture medium. AH were able to detect low parasite number ( 1) per tube in $43 \%$ of tubes seeded. In case the inocula contained a low number of parasite, centrifugation and washing of the infected blood samples before inoculation resulted in a lower positivity as compared to samples that were not centrifuged. In addition, we observed that LIT showed to be a more adequate medium than BHI and keeping samples for more than 4 to $16 \mathrm{hr}$ before inoculation resulted in a reduction of positivity of $30 \%$ to $70 \%$, respectively as compared to cultures performed with parasites recently isolated. In hemocultures, prepared with ( $\sim 1$ to 10 trypomastigotes per tube) the parasite survival was better when compared to parasites kept at $4^{\circ} \mathrm{C}$ as compared to parasites kept at $28^{\circ} \mathrm{C}$. From these results we concluded that manipulation of blood containing low numbers of trypomastigotes, should be fast, by preference im- mediately after its collection and under low temperature. Subsequently, we performed hemocultures of 162 untreated chagasic chronic patients from an outpatient clinic (Dr JR Cançado, Faculty of Medicine, Federal University of Minas Gerais). These patients were equally distributed among both sexes and none of them had previously been submitted to parasitological tests (Luz 1998). Each hemoculture was prepared with thirty $\mathrm{ml}$ of heparinized blood immediately centrifuged at 1,000 $\mathrm{g} / 10 \mathrm{~min} / 4^{\circ} \mathrm{C}$ and next washed only once. Afterwards, the packed red blood cell was carefully aliquoted, from the top to the bottom, using a Pasteur pipete ( $\pm 3 \mathrm{ml}$ aliquots). The first tube (seven in total) contained the buffy coat and all tubes were incubated at $28^{\circ} \mathrm{C}$. Performing only one test $76 \%$ of the patients was considered positive by hemoculture, in accordance with the preliminary dates of 52 of these patients (Luz et al. 1994). No significant differences could be observed in positivity of hemocultures in relation to sex and age (mean age $43 \pm 14$ years old) but the oldest subjects with ages ranging from 51 to 82 years old and the youngest with ages ranging 13 to 20 years old, presented a positivity of $91 \%$ and $100 \%$, respectively. These patients were classified according to parasite load in a low (one or two positives tubes) and 
a high parasitemia group (three to seven positive tubes). According to these criteria, $62 \%$ of the patients presented a low parasitemia. We observed that using the buffy coat gave significantly more positive results $(80 \%)$ than the others tubes (Luz 1998). Mora (1996) also showed increased positivity $(47.5 \%)$ using the buffy coat. The concentration of parasites in the buffy coat might simplify the technique since a smaller number of tubes per patient will be used which makes the test more suitable for parasitological diagnosis.

In conclusion, higher positivity of hemocultures can be attained: (a) using the LIT medium; (b) using the buffy coat; (c) increasing the period of culture up to 120 days PI; (d) diminishing the lapse of time between collection and inoculation of the sample; (e) reducing manipulation of the blood samples. Barbosa et al. (1993) observed from ten patients a positivity rate of $20 \%$ to $60 \%$, respectively, performing hemocultures with or without centrifugation of the blood. Fernandes et al. (1995), also observed that reduced manipulation of the blood sample increased the positivity of the hemoculture. Under precarious field conditions they obtained a positivity of $53.3 \%$ in 16 chronic chagasic patients and a low (around 2\%) culture contamination.

Several studies confirmed that hemoculture can be a sensitive test for the diagnosis of Chagas disease. Emphasize should be given to improve parasitological methods to detect the parasite especially considering patients submitted to specific treatment. Persisting negativity of the hemocultures in these patients strongly suggests that parasite might be eliminated.

\section{ACKNOWLEDGEMENTS}

To Jolande Disch for coments and suggestions on this manuscript.

\section{REFERENCES}

Albuquerque RDR, Fernandes LAR, Funayama GK, Filho FF, Siqueira AF 1972. Hemoculturas seriadas com o meio de Warren em pacientes com reação de Guerreiro Machado positiva. Rev Inst Med Trop São Paulo 14: 1-5.

Barbosa W, Czerewuta AC, Oliveira RL 1983. Tentativa de isolamento primário de $T$. cruzi de pacientes crônicos de doença de Chagas por hemocultura agentes bloqueadores. Rev Pat Trop 12: 155-163.

Cerisola JA 1975. El xenodiagnóstico. PAHO Session III B.4.

Chiari E 1992. Diagnostic tests for Chagas disease, $p$. 153-164. In S Wendel, Z Brener, ME Camargo \& A Rassi (eds), Chagas Disease (American Trypanosomiasis): Its Impact on Transfusion and Clinical Medicine, ISBT, São Paulo.

Chiari E, Brener Z 1966. Contribuição ao diagnóstico parasitológico da doença de Chagas na sua fase crônica. Rev Inst Med Trop São Paulo 8: 134-138.

Chiari E, Dias JCP 1975. Nota sobre uma nova técnica de hemocultura para diagnóstico parasitológico na doença de Chagas na sua fase crônica. Rev Soc Bras Med Trop IX: 133-136.

Chiari E, Dias JCP, Lana M, Chiari CA 1989. Hemocultures for the parasitological diagnosis of human chronic Chagas disease. Rev Soc Bras Med Trop 22: 19-23.

Coura JR, Abreu LL, Willcox HPF, Petana W 1991. Evaluation of the xenodiagnosis of chronic Chagas patients infected ten years or over in an area where transmission has been interrupted - Iguatama and Pains, west Minas Gerais State, Brazil. Mem Inst Oswaldo Cruz 86: 395-398.

Fernandes AJ, Diotaiuti L, Azeredo BVM, Busek SU, Chiari E 1995. Viabilidade da utilização da hemocultura no diagnóstico da infecção pelo Trypanosoma cruzi em amostras coletadas em condições de campo. Rev Soc Brasil Med Trop 28: 123.

Flores MA, Trejos A, Paredes AR, Ramos AY 1966. El método de concentración de Strout en el diagnóstico de la fase aguda de la enfermedad de Chagas. Bol Chil Parasitol 21: 38-39.

Freitas JLP 1952. O diagnóstico de laboratório da moléstia de Chagas. Rev Clin São Paulo 28: 11-20.

Fuente C, Urjel R, Darras C, Saucedo E 1985. Uso de tubos de microhematocrito para el diagnostico rapido de la enfermedad de Chagas y malaria. Ann Soc belge Méd trop 65: 95-99.

Galvão LMC, Nunes RMB, Cançado JR, Brener Z, Krettli AU 1993. Lytic antibody titre as a means of assessing cure after treatment of Chagas disease: a 10 years follow-up study. Trans $R$ Soc Trop Med Hyg 87: 220-223.

Jörg ME, Báez VJ 1993. Parasitemia en infectados cronicos por Trypanosoma cruzi, indeterminados y sintomaticos, evidenciada por hemocultivo. $C M$ Publicación Médica 6: 71-79.

Junqueira ACV, Chiari E, Wincker P 1996. Comparison of the polymerase chain reaction with two classical parasitological methods for the diagnosis of Chagas disease in an endemic region of north-eastern Brazil. Trans $R$ Soc Trop Med Hyg 90: 129-132.

Luz ZMP 1998. Hemoculturas em Indivíduos na Fase Crônica pelo Trypanosoma cruzi: Modificações na Metodologia Visando à Simplificação e Aumento da Sensibilidade da Técnica, MSc Thesis, Instituto Oswaldo Cruz, 87 pp.

Luz ZMP, Coutinho MG, Cançado JR, Krettli AU 1994. Hemocultura: técnica sensível na detecção do Trypanosoma cruzi em pacientes chagásicos na fase crônica da doença de Chagas. Rev Soc Brasil Med Trop 27: 143-148.

Marsden PD, Mott KE, Prata A 1969. The prevalence of Trypanosoma cruzi parasitemia in 8 families in an endemic area. Gaz Med Bahia 69: 65-69.

Minter-Goedbloed E, Minter DM, Marshall TFC 1978. Quantitative comparison between xenodiagnosis and haemoculture in the detection of Trypanosoma (Schizotrypanum) cruzi in experimental and natural chronic infections. Trans R Soc Trop Med Hyg 72: 217-225. 
Mora MXG 1996. Avaliação de uma técnica modificada de hemocultura para $T$. cruzi, na forma crônica da doença de Chagas em uma área endêmica. Rev Soc Bras Med Trop 29: 515-516.

Mourão OG, Chiari E 1975. Comprovação parasitológica na fase crônica da doença de Chagas por hemoculturas seriadas em meio LIT. Rev Soc Bras Med Trop 9: 215-219.

Mourão OG, Mello OC 1975. Hemoculturas para o diagnóstico parasitológico na fase crônica da doença de Chagas. Rev Soc Bras Med Trop IX: 183-188.

Neal RA, Miles RA 1977. The sensitivity of culture methods to detect experimental infections of Trypanosoma cruzi and comparison with xenodiagnosis. Rev Inst Med Trop São Paulo 19: 141-212.

Pifano CF 1954. El diagnostico parasitologico de la enfermedad de Chagas cronica. Estudio comparativo entre la gota gruesa, el xenodiagnostico, el hemocultivo y las inoculaciones experimentales en animales sensibles. Arch Venezol Patol y Parasit Med 2: $120-155$.

Schenone H, Alfaro E, Rojas A 1974. Bases y rendimiento del xenodiagnóstico en la infeceión chagásica humana. Bol Chil Parasitol 29: 24-26. 